\title{
Rapid growth of petroleum coke consumption and its related emissions in China
}

Yuli Shan ${ }^{1}$, Dabo Guan ${ }^{1,2, *}$, Jing Meng ${ }^{3}$, Zhu Liu ${ }^{1,2}$, Heike Schroeder ${ }^{1}$, Jianghua Liu ${ }^{4}$, Zhifu $M i^{5}$

1 Water Security Research Centre, Tyndall Centre for Climate Change Research, School of International Development, University of East Anglia, Norwich NR4 7TJ, UK

2 Department of Earth System Sciences, Tsinghua University, Beijing 100080, China

3 Department of Politics and International Studies, University of Cambridge, Cambridge CB3 9DT, UK

4 Institute of Finance and Economics Research, School of Urban and Regional Science, Shanghai University of Finance and Economics, Shanghai 200433, China

5 Bartlett School of Construction and Project Management, University College London, London WC1E 7HB, UK

${ }^{*}$ Corresponding author. Email address: Dabo.Guan@uea.ac.uk (Dabo Guan)

\begin{abstract}
Petroleum coke, a non-environmentally friendly energy source, is gradually replacing other power fuels in China's industrial enterprises because of its price advantage. Petroleum coke has high emission factors and thus emits more greenhouse gases (GHGs) and air pollutants than even raw coal. This study first examines the rapid growth of petroleum coke consumption in China since 2010 by industry sector and region and then estimates the petroleum coke-related emissions. We conclude that the total consumption of petroleum coke increased by $18.9 \%$ from 2010 to 2016 and that the industry final consumption for burning in boilers increased dramatically (by 158.2\%). Petroleum cokerelated $\mathrm{CO}_{2}$ emissions reached 28 million tonnes in 2016, whereas $\mathrm{CH}_{4}$ and $\mathrm{N}_{2} \mathrm{O}$ emissions totaled 870 and 143 tonnes, respectively. The increased use of petroleum coke will increase the urgency for the development of climate change mitigation and emissions reduction measures in China. We propose several possible policy suggestions for petroleum coke management and emissions control, such as strongly restricting the production and import of high-sulphur petroleum coke, as well as burning petroleum coke to provide power; more power plants and industrial kiln stoves/boilers should be equipped with efficient decontamination systems; the development of advanced industrial processes and the clean utilization of petroleum coke should be encouraged.
\end{abstract}

Keywords: Petroleum Coke; Greenhouse Gas Emissions; Air Pollutants; China

\section{Introduction}

China is the largest energy consumer in the world, and its energy consumption pattern is "rich coal, deficient oil, and lean gas". Coal and its related products constitute approximately $70 \%$ of the total energy consumption in China. Under pressure from environmental protection groups and international negotiations on climate change mitigation, China's government has proposed several policies to control coal consumption in recent years [1]. For example, according to the "Strategic action plan for energy development (2014-2020)", the total national coal consumption must fall below 4.2 billion tonnes by 2020 [2]. After implementing a series of energy/emissions control policies, the coal share in China decreased from $72.5 \%$ in 2007 to $62.0 \%$ in 2016. Simultaneously, China strived to develop renewable and clean energies, such as natural gas, hydropower, and nuclear power. 
Renewable and clean energies now contribute $19.5 \%$ of overall energy consumption and have almost doubled since 2000 (9.5\%).

Overall, China's energy structure appears to be developing along a low-carbon path. However, a few industrial enterprises and power plants have recently begun to use cheap but environmentally unfriendly energy sources, especially petroleum coke. According to the Intergovernmental Panel on Climate Change (IPCC) guidelines, "petroleum coke is defined as a black solid residue, obtained mainly by cracking and carbonizing of petroleum derived feedstocks, vacuum bottoms, tar and pitches in processes such as delayed coking or fluid coking. It consists mainly of carbon (90 to 95 percent) and has a low ash content. It is used as a feedstock in coke ovens for the steel industry, for heating purposes, for electrode manufacture and for production of chemicals" [3]]. According to a previous study that compared emissions factors [4], petroleum coke emits 2.21 times the $\mathrm{CO}_{2}, 6.15$ times the $\mathrm{CH}_{4}$, and 5.48 times the $\mathrm{N}_{2} \mathrm{O}$ emitted by lignite coal during combustion. Lignite coal is primarily used as thermal coal in power plants and industrial boilers in China. Therefore, petroleum coke is a more carbon- and pollution-intensive energy source, even when compared with raw coal and crude oil. The usage of petroleum coke, especially for combustion, degrades the local air quality and threatens residents' health [ $[$ ].

Recently, the increasing consumption of petroleum coke in China has attracted more and more attentions $[6,7]$. Petroleum coke production and consumption have increased rapidly in China. From 2010 to 2016, the production of petroleum coke increased by $40.9 \%$, and its use in industrial final combustion increased by $158.2 \%$, as it was used in kiln stoves/boilers to provide power. However, accurate accounts of China's petroleum coke consumption and its related environmental impacts are still lacking.

Previous studies on China's energy consumption and related emissions generally concentrated on either overall regional issues [8-10] or major energy sources, such as coal $[11,12]$ or oil [13]. There are barely any studies available that target petroleum coke consumption in China. Those that exist can be divided into two categories. First, there are those that discuss the environmental impacts of petroleum coke consumption. For example, Caruso, Zhang [14] use Detroit and Chicago as cases to explore the petroleum coke's effects on urban environment and residential health. McKee and White [15] report on the effects of petroleum coke on aquatic mammals. Second, there are studies that discuss the clean utilization of petroleum coke from a technical perspective. For example, Wang, Anthony [16] discuss the possible $\mathrm{CO} 2$ recovery and sulphur removal approaches for petroleum coke combustion in power plants. Zou, Zhou [17] introduce a gasification technology to convert the abundant petroleum coke into syngas with near zero emissions. There are still not many studies that discuss petroleum coke management and control from a socio-economic perspective.

Considering petroleum coke's adverse effects on the environment and air quality, the Chinese government should take actions to restrain the combustion of petroleum coke. However, the Chinese government has not yet recognized the hazard posed by the widespread use of petroleum coke. Indeed, in the "10 key energy conservation projects during the $11^{\text {th }}$ five-year plan (2006-2010)", the use of petroleum coke as a replacement for fuel oil (burnt in oilfield exploitation) and heavy oil (used in the production of construction materials) is actually encouraged [18]. Only in the "Air pollution prevention and control action plan", which was published in 2013 [19], did the government intensify its controls on the import of high-sulphur petroleum coke. However, this policy was issued without any 
detailed measures. To some extent, this is restricted by the lack of accurate accounts of petroleum coke combustion. Understanding the consumption characteristics and related emissions is the first step of petroleum coke management. This is the first study that analyses the increasing consumption of petroleum coke in China and its regions. We also estimate the related greenhouse gas and air pollutant emissions. Such socio-economicemission analysis can not only provide robust and transparent data support for petroleum coke management, air pollution and greenhouse gas emissions control policy-making in China, but also support the clean utilization of the energy source.

\section{Methods and data source}

To elucidate the adverse effects of China's growing petroleum coke consumption on the climate and air quality, we estimate the $\mathrm{CO}_{2}, \mathrm{CH}_{4}$, and $\mathrm{N}_{2} \mathrm{O}$ emissions from petroleum coke combustion in this country. All three gases are considered greenhouse gases (GHGs). $\mathrm{CH}_{4}$ and $\mathrm{N}_{2} \mathrm{O}$ are also classified as air pollutants.

According to the IPCC guideline []ㅡ, this study calculates the emissions with the consumption data of petroleum coke. Generally, petroleum coke is used in two ways in China. 1) Over $60 \%$ of the petroleum coke is consumed as a raw material, i.e., for a non-energy use, such as in the smelting of steel or aluminium and the manufacturing of graphite (shown as the grey bar in Figure 1); 2) Less than $40 \%$ of the petroleum coke is combusted in industrial kiln stoves/boilers and in power plants as fuel (see the orange and dark-blue bar in Figure 1). As the first part of petroleum coke is used as raw material during industrial process, most of the carbon elements are converted into other organics, rather than $\mathrm{CO}_{2}$. Therefore, the nonenergy use of petroleum coke emits only low levels $\mathrm{CO}_{2}$ emissions $[\underline{8}, \underline{20}, \underline{21}]$. This study only considers the emissions induced by petroleum coke combustion. The emissions from fossil fuel combustion are estimated in Equation 1.

$E=A D \times N C V \times E F \times O \times E C R$

Equation 1

where $A D$ means Activity Data, refers to petroleum coke burning consumption in this study. The consumption data of petroleum coke $(A D)$ were collected from China and its 30 provinces' energy balance tables from 2010-2016 [22]. Considering the statistical gap between China's national and regional energy data [23], we scaled down the provincial data to match the national data. Because of its relatively small consumption amount, petroleum coke was not listed as a separate energy type in China's energy statistics system until 2010 and was previously included in other petroleum products. Figure 1 presents the supply and consumption of petroleum coke in China since 2010. 


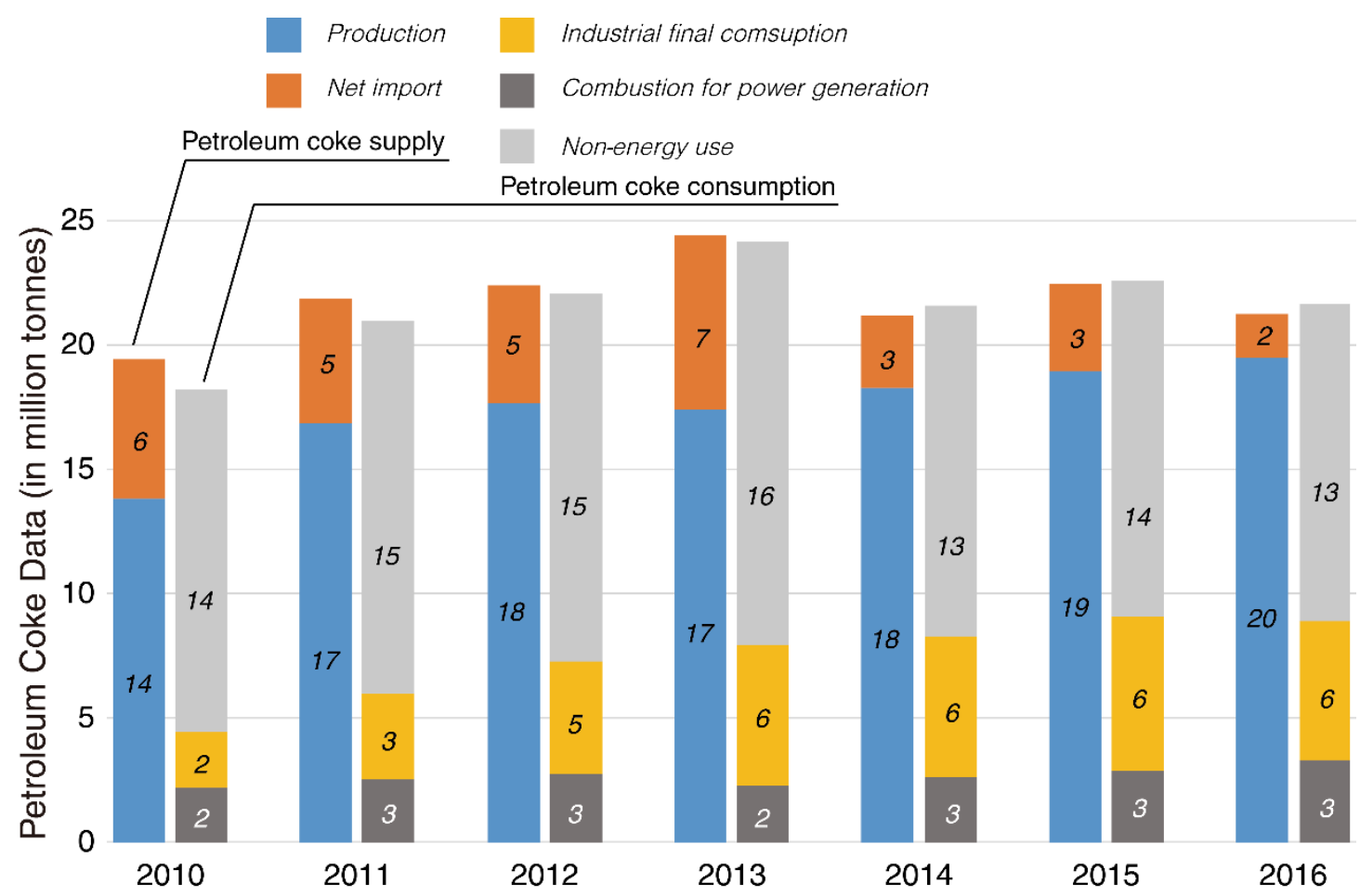

Figure 1. Supply and consumption of petroleum coke in China.

As for the emission factors in Equation 1, NCV means Net Calorific Value, refers to the heat released during per physical unit of petroleum coke combustion; $E F$ (Emission Factor) is the $\mathrm{CO}_{2}, \mathrm{CH}_{4}$, and $\mathrm{N}_{2} \mathrm{O}$ emissions while per Joule heat releasing. As not all of the fossil fuel could be fully combusted in boilers, we time an oxygenation efficiency $(O)$ in the equation, which refers to the boilers' oxidation ratio of petroleum coke in this study. Because no research has specifically focused on China's petroleum coke emissions factors to date, we adopted the IPCC's default values. The $N C V$ of petroleum coke is $32.5 \mathrm{TJ} / \mathrm{Gg}$. The $E F$ values of $\mathrm{CO}_{2}$, $\mathrm{CH}_{4}$, and $\mathrm{N}_{2} \mathrm{O}$ are $97,500,3$, and $0.6 \mathrm{Kg} / \mathrm{TJ}$, respectively. The default oxygenation efficiency is 1.

$E C R$ in Equation 1 refers to Emission Control Ratio. Because most of the power plants in China have been equipped with denitration systems (low- $\mathrm{NO}_{x}$ boilers), we assign a control ratio of $70 \%$ to the estimated $\mathrm{N}_{2} \mathrm{O}$ emissions from petroleum coke burnt in power plants equipped with low- $\mathrm{NO}_{x}$ boilers [24]. The $70 \%$ control ratio means that $30 \%$ of the $\mathrm{N}_{2} \mathrm{O}$ emissions can be removed by the denitration system. According to the literature, currently, such denitration systems are installed in approximately $75 \%$ of power plants in China [24]. Thus, the ECR for power plants is $52.5 \%$. In contrast, industrial boilers usually have small power capacities; thus, it is uneconomical to install denitration systems on them. Consequently, the installation rate of denitration equipment on industrial boilers is quite low. Therefore, we assume that $\mathrm{N}_{2} \mathrm{O}$ emissions from petroleum coke burnt in industrial boilers are not controlled [24], and as a result, the ECR is $100 \%$ for the industrial boilers.

All data and results in this study can be downloaded from China Emission Accounts \& Datasets (CEADs, www.ceads.net) for free after registration. 


\section{Results and discussion}

\subsection{Production and import}

Petroleum coke is a by-product produced by petroleum refineries. Heavy crude produces more petroleum coke than light crude [25]. The national overall petroleum coke production in 2016 was 19.5 million tonnes. China's petroleum coke production increased by $40.9 \%$ (5.7 million tonnes) from 2010 to 2016, probably because of long-term engineering service contracts between China and Iraq, which started in 2003, and the oil exploration agreements between China's national petroleum corporation and Abu Dhabi's national oil company, which were signed in 2014 [26].

Petroleum refineries are concentrated in several primary oilfields or petrochemical bases in China. Taking the year 2016 as an example, the red dots in Figure 2 show the petroleum production of a few primary oilfields, with larger dots representing higher productions. Shengli oilfield in Dongying, Shandong province, is the largest petroleum coke producer. It produced 5.8 million tonnes of petroleum coke in 2016 , accounting for $30.6 \%$ of the national overall production. Guangdong (Maoming petrochemical base, 1.8 million tonnes), Jiangsu (Jiangsu oilfield, 1.7), Liaoning (Liao river oilfield,1.7), Xinjiang (Karamay oilfield,1.4), and Zhejiang (Zhejiang oilfield, 1.2) also produced large quantities of petroleum coke. These top 6 oilfields (petrochemical bases) produced $70.2 \%$ of the total petroleum coke in 2016.

The variation of each province's petroleum coke production may be credited to the province's different natural resources endowment as well as the oilfield company's industry structure. For example, the Shengli oilfield (locates in Dongying, Shandong) is the second largest oil field in China. It produced 27.1 million tonnes of crude oil in 2015, accounting for $12.6 \%$ of China's total crude oil production (214.6 million tonnes). The huge crude oil production provides Shengli oilfield the precondition of oil refinery and petroleum coke production. At the same time, the Shengli oilfield company is the largest oil refinery enterprise in China with a refinery capacity of 2.2 million tonnes per year. Petroleum coke is one of the eight major products of Shengli oilfield [27]. On the contrary, despite Daqing oilfield (the largest oilfield in China, located in Daqing, Heilongjiang) producing roughly 40 million tonnes of crude oil every year, it does not have many petroleum coke production industries [28]. This may explain why the petroleum coke production of Heilongjiang province ( 0.1 million tonnes) is much smaller than that of Shandong province (5.8 million tonnes). 


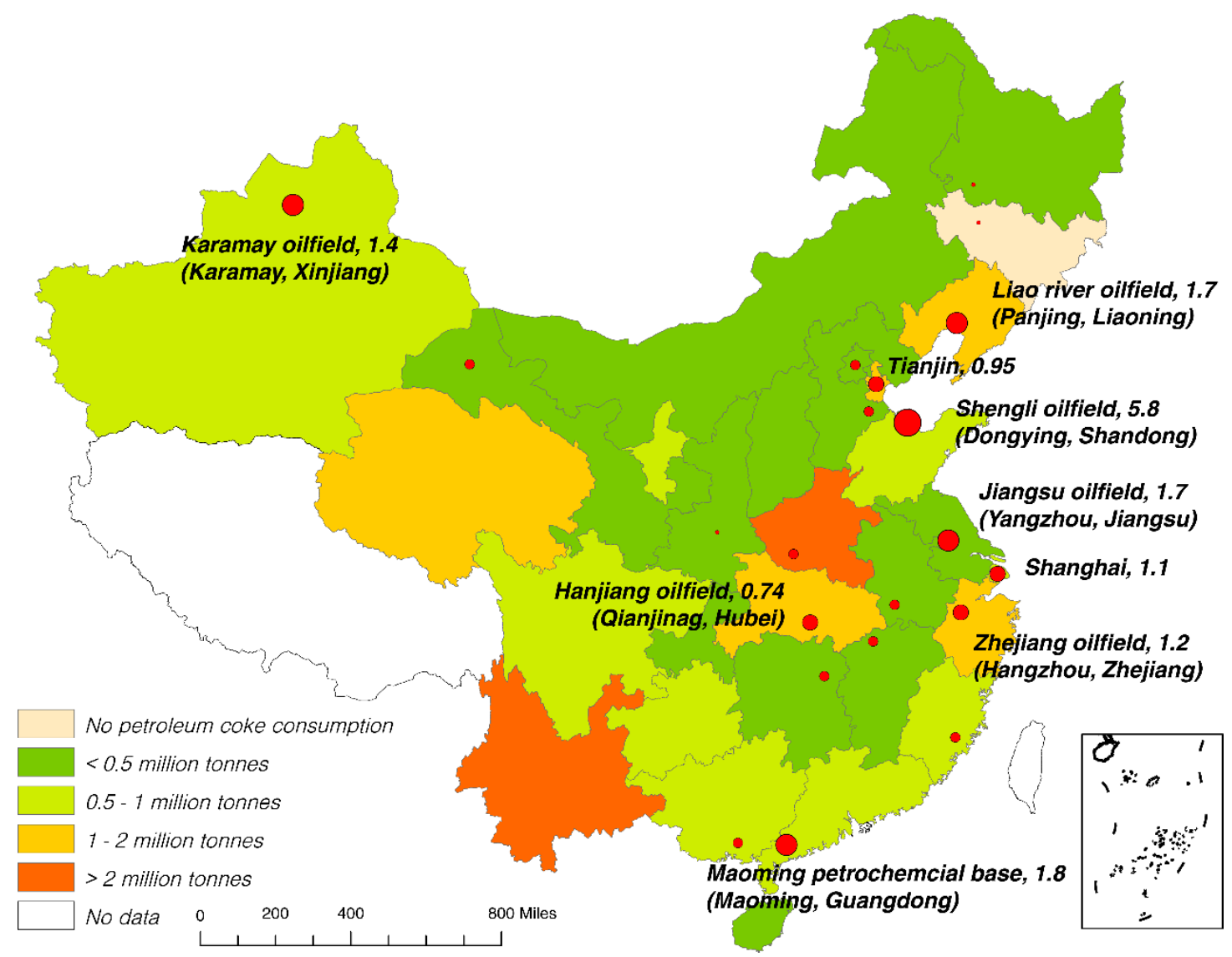

Figure 2. Production and total consumption of petroleum coke by provinces in 2016.

Figure 3 shows that the increasing petroleum coke production in China can be primarily attributed to Shandong province (i.e., the Sinopec Shengli oilfield company in Dongying). Shandong increased its petroleum coke output by 4.5 million tonnes during the seven-year study period, accounting for $79.6 \%$ of the national increase. In other provinces, production either remained stable or increased only slightly.

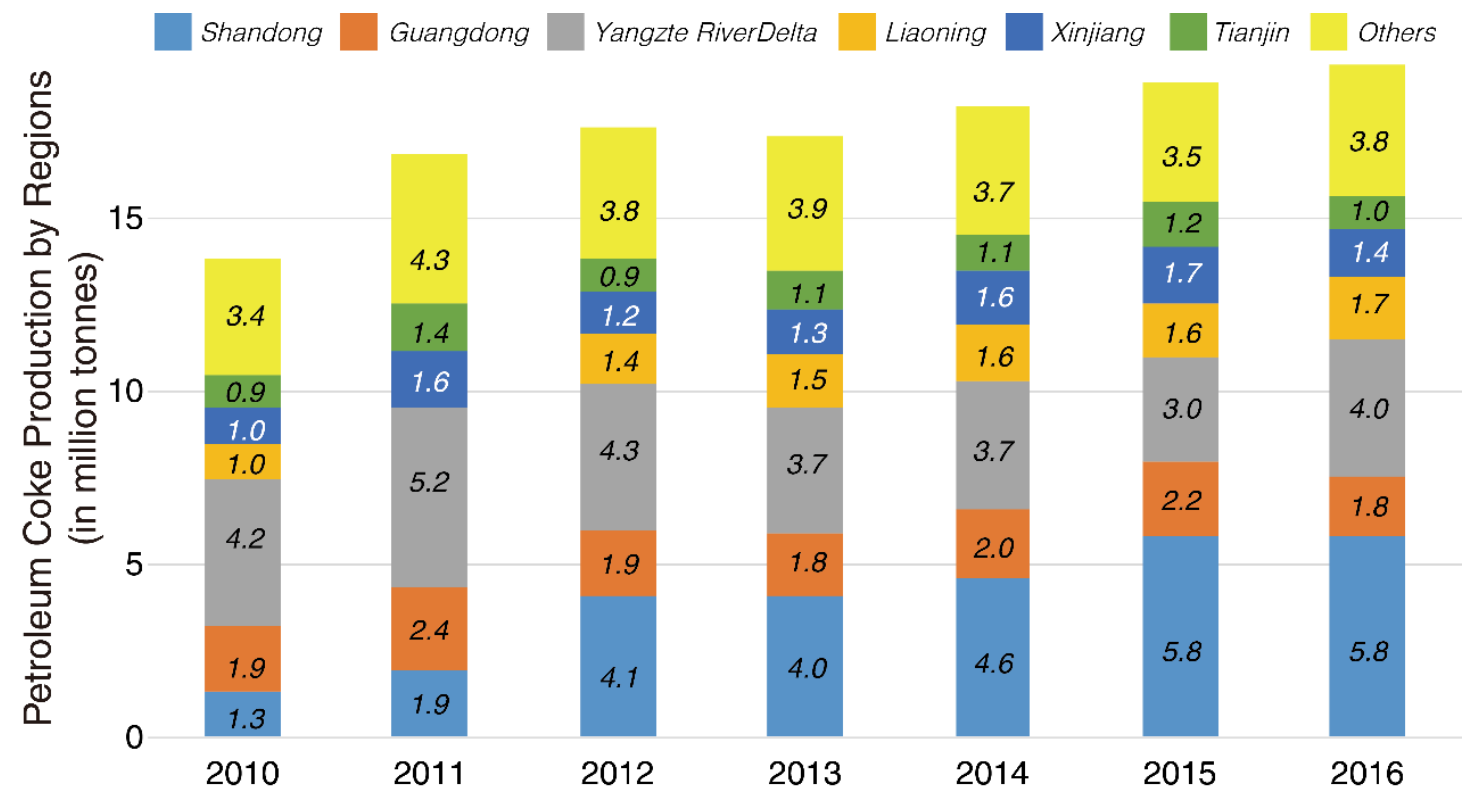

Figure 3. Production by 6 primary regions. 
Note: Here, the Yangtze River Delta includes Shanghai, Jiangsu, and Zhejiang provinces. Because of the poor data quality of some of China's regions, we do not have the production data for Liaoning in 2011 (shown as 0 ton here). Compared with the data from similar years, we assume that Liaoning produced approximately 1.2 million tonnes of petroleum coke in 2011.

The import volume of petroleum coke fluctuated widely. China imported roughly 7.5 million tonnes of petroleum coke per year before 2013 , representing approximately $50 \%$ of its local production. Subsequently, the imports increased to 9.3 million tonnes in 2013 and then suddenly dropped to 4.3 million tonnes in 2016 . About $50 \%$ of the imported petroleum coke was from the USA (Table 1). China is the third-largest consumer of petroleum coke produced in the USA (10\%-20\%), followed by India and Japan [29].

Table 1. Petroleum coke imported by China and exported by the USA.

\begin{tabular}{r|rrr|rrr}
\hline \multirow{2}{*}{ Year } & \multicolumn{3}{|c|}{ USA exports (million barrels) } & \multicolumn{3}{c}{ China imports (million tonnes) } \\
\cline { 2 - 7 } & To China & Total export & Percentage & From USA & Total import & Percentage \\
\hline 2010 & 15.2 & 163.9 & $9.25 \%$ & 2.1 & 7.7 & $26.64 \%$ \\
2011 & 24.8 & 182.2 & $13.59 \%$ & 3.4 & 8.1 & $41.54 \%$ \\
2012 & 26.2 & 184.2 & $14.21 \%$ & 3.6 & 7.0 & $50.62 \%$ \\
2013 & 38.4 & 191.2 & $20.10 \%$ & 5.2 & 9.3 & $55.91 \%$ \\
2014 & 20.8 & 197.5 & $10.55 \%$ & 2.8 & 5.4 & $52.99 \%$ \\
2015 & 18.4 & 196.5 & $9.34 \%$ & 2.5 & 5.9 & $42.40 \%$ \\
2016 & 14.3 & 209.7 & $6.84 \%$ & 2.0 & 4.3 & $45.19 \%$ \\
\hline
\end{tabular}

Data source: Data relating to the USA's exports were obtained from the U.S. Energy Information Administration [29]. Data about China's imports from the USA were calculated based on a unit conversion factor (0.136 tonnes of oil equivalent per barrel) [30], whereas China's total imports were obtained from China's energy statistical yearbooks [22].

Among the 4.3 million tonnes of petroleum coke imported in 2016, 84.8\% (3.7 million tonnes) was imported by Shandong. However, although Shandong imported a large amount of petroleum coke, we cannot conclude that all of the imported petroleum coke was consumed in Shandong province. Indeed, Shandong province consumed just 0.8 million tonnes of petroleum coke in 2016. Together with that produced in Shandong, most of the imported petroleum coke was transported to other provinces (8.7 million tonnes in total). Therefore, Sinopec Shengli oilfield company in Shandong is the primary petroleum coke production and transshipment base in China.

\subsection{Consumption}

The increasing production and imports led to a sharp increase in petroleum coke consumption. In total, China consumed 21.7 million tonnes of petroleum coke in 2016, increasing from 18.3 million tonnes in 2010.

Although most of the petroleum coke was used as a raw material (12.8 million tonnes in 2016, accounting for $58.9 \%$ of the overall consumption), the additional 8.9 million tonnes consumed is primarily attributable to combustion. Petroleum coke combustion increased by 101.62\% (4.5 million tonnes) from 2010 to 2016. This growth rate is remarkably high compared with those of total energy and raw coal. Indeed, total energy combustion increased by $21.9 \%$ (from $3,128.4$ to 3814.4 million tonnes of standard coal equivalent according to calorific value calculations), whereas raw coal combustion increased by $8.0 \%$ (from 2,589.5 to 2,797.7 million tons). 
Petroleum coke combustion is presented by sector in Figure 4. For clarity, we divide the petroleum coke consumption by sector into two parts according to the method of consumption: "Input as industrial material (non-energy use)" and "Burning consumption". The "manufacture of non-metallic mineral products" (MNMP) sector consumed most of the petroleum coke in 2016 (60.0\%), followed by the "production and supply of electric and heat power" (PSEH) sector (15.89\%), "smelting and pressing of non-ferrous metals" (SPNM) sector (9.33\%), "processing of petroleum, coking and processing of nuclear fuel" (PPCN) sector (8.91\%), "manufacture of raw chemical materials and chemical products" (MRC) sector (3.08\%), and "smelting and pressing of ferrous metals" (SPFM) sector (2.06\%). Other industries (OI) include "Mining and processing of non-ferrous metal ores", "manufacture of liquor, beverages and refined tea", "manufacture of paper and paper products", "manufacture of metal products", "manufacture of electrical machinery and apparatus", and "other manufacturing".

Sectoral Consumption of Petroleum Coke (in million tonnes)

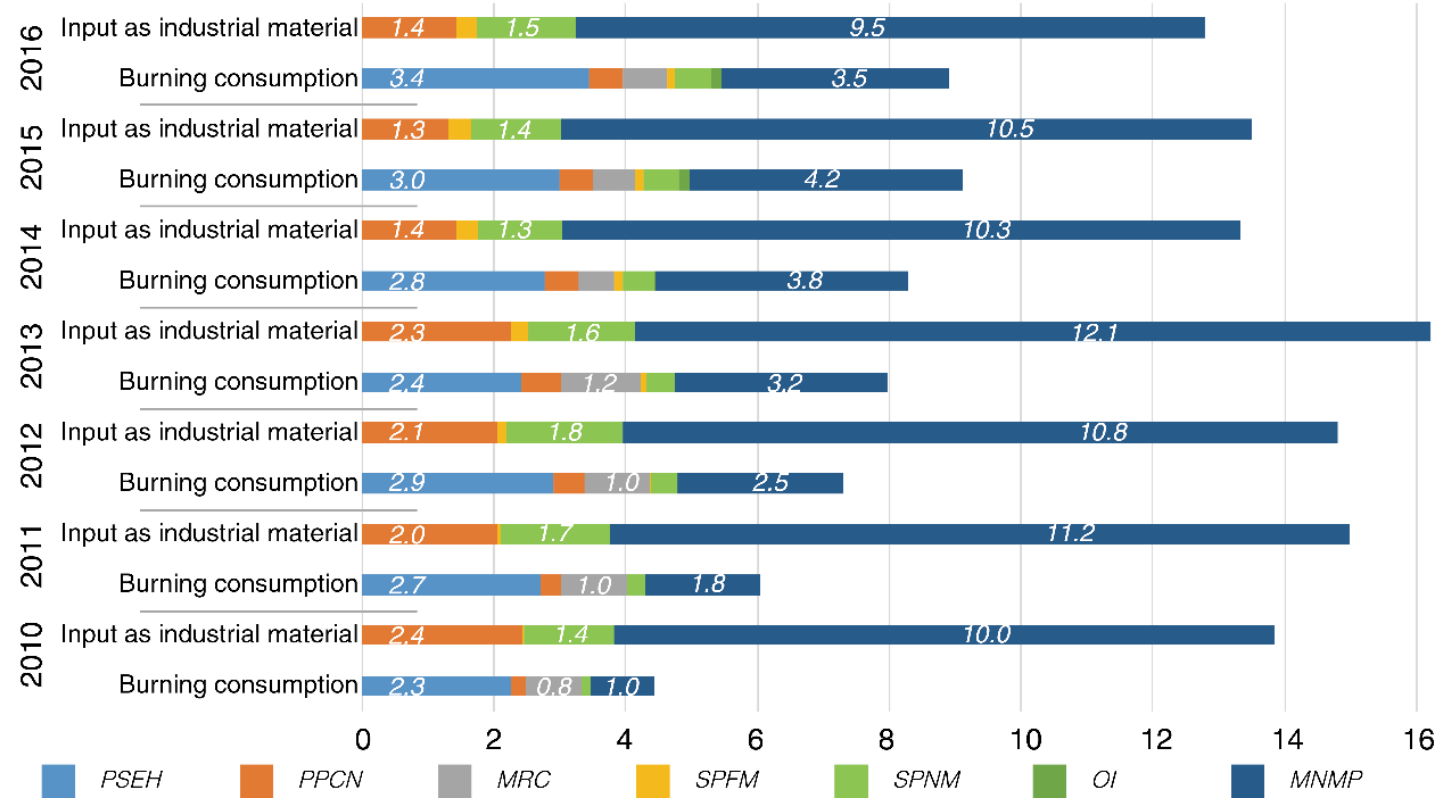

Figure 4. Petroleum coke consumption by sector in China.

The raw material input of petroleum coke fluctuated slightly during the seven-year study period, and even appeared to decrease $(-7.6 \%)$ in 2016. This was likely the result of China's temporary economic slowdown [31], during which some industrial enterprises reduced their production. As a raw material, in China, petroleum coke is primarily used in the MNMP sector to produce graphite, accounting for $74.72 \%$ of the total material input in 2016 . The PPCN sector used 1.4 million tonnes of petroleum coke, whereas 1.5 million tonnes were used as prebaked anodes to electrolyze aluminium in the SPNM sector. The remaining 0.3 million tonnes were used in the SPFM sector for steelmaking.

During this period, the burning consumption of petroleum coke increased at an alarming rate. The amount doubled from 4.4 million tonnes in 2010 to 9.1 million tonnes in 2015 and finally to 8.9 million tonnes in 2016. Among the 6-petroleum coke-consuming sectors, MNMP burnt 3.5 million tonnes in 2016, representing an increase of $258.0 \%$ since 2010 . The petroleum coke combusted in power plants for electricity and heat generation remained stable at approximately 2.8 million tonnes throughout the seven-year period. As a raw material utilized in industrial processes, the non-energy uses of petroleum coke emit little 
GHGs or air pollutants. In contrast, combustion emits large quantities of carbon, nitrogen, and oxidized sulphur. Therefore, the combustion of petroleum coke is the primary emissions source and should be considered as a key regulatory target.

As discussed above, the raw material input of petroleum coke decreased since 2014 as some industrial enterprises reduced their production, whereas the combustion of petroleum coke in industrial enterprises (excluding combustion in power plants) increased rapidly (i.e., by $158.24 \%$ since 2010). This trend strongly suggests that industrial enterprises are replacing other fuel types with petroleum coke, probably because of petroleum coke's price advantage. Up to $35 \%$ of the cost can be saved if a power plant co-fires petroleum coke with coal compared with fires coal alone [32]. China's government should pay close attention to this "replacement" fuel, as its use does not fit with the country's energy mix optimization strategy and low-carbon development plans.
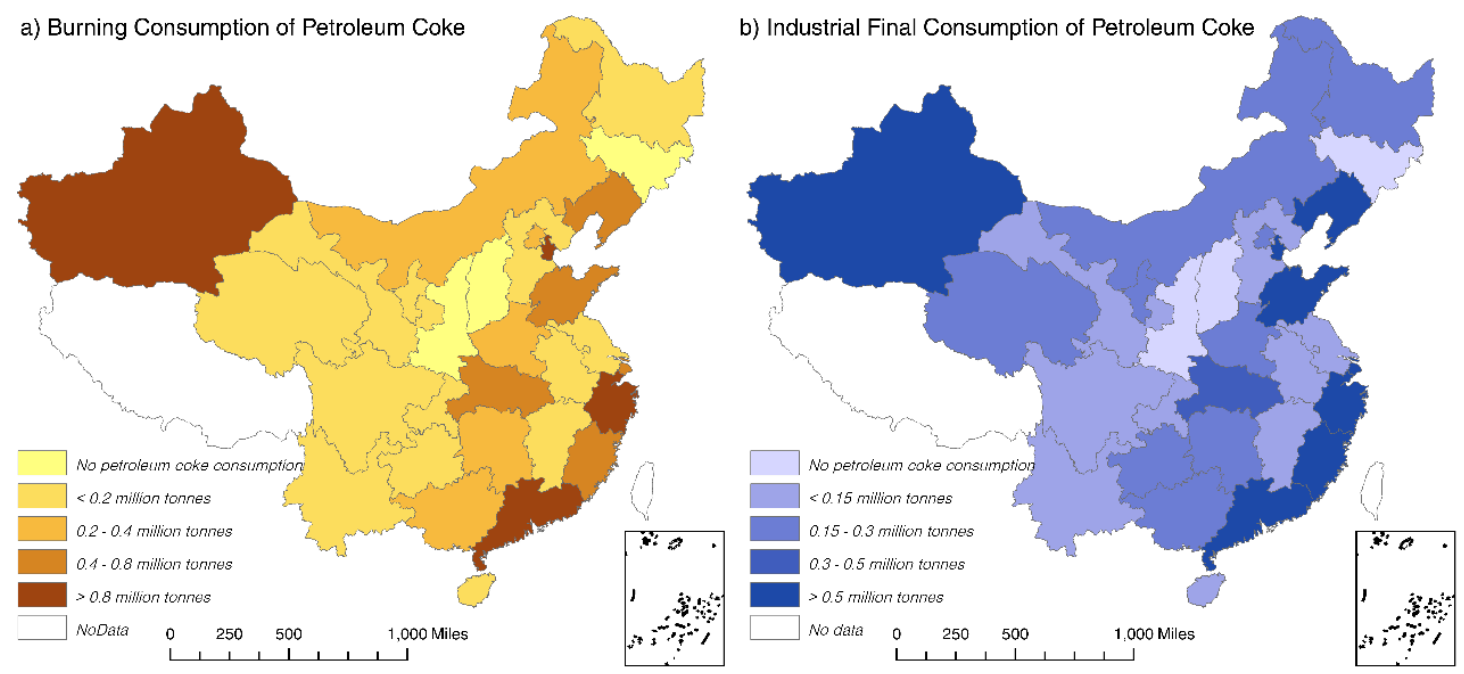

Figure 5. Combustion of petroleum coke by province in 2016.

Take 2016 as an example (Figure 2). The top five petroleum coke-consuming provinces were Henan (2.8 million tonnes, 13.0\%), Yunnan (2.8, 12.9\%), Qinghai (1.9, 8.8\%), Liaoning (1.8, $8.6 \%)$, and Hubei $(1.4,6.4 \%)$. Jilin, and Hainan consumed no petroleum coke at all. Although most of the petroleum coke is used as a raw material in industrial processes, that which is used for burning is the relatively important part in terms of emissions. Therefore, we analysed the distribution of the burning consumption of petroleum coke, as shown in Figure 5. The industry final consumption refers to the petroleum coke burnt in industrial kiln stoves/boilers to provide power, excluding combustion in power plants. The burning consumption is equal to industry final consumption plus that burnt in power plants for electricity and heat generation.

Tianjin (1.1 million tonnes, $13.2 \%)$ and Guangdong $(0.9,10.7 \%)$ burnt the most petroleum coke, followed by Xinjiang $(0.8,9.7 \%)$, Zhejiang $(0.8,9.7 \%)$, Shanghai $(0.7,8.2 \%)$, Shandong $(0.6,6.7 \%)$, and Liaoning $(0.5,6.6 \%)$. These seven super-burning-consumption provinces (dark-yellow regions in Figure 5 -a) contributed $64.7 \%$ of the overall burning consumption in China. Unlike other super-burning-consumption provinces, Hebei, Inner Mongolia, Liaoning, Heilongjiang, Jiangsu, Anhui, Hainan, Chongqing, Sichuan, Guizhou, Yunnan, Gansu, Qinghai, Ningxia, and Xinjiang only burnt petroleum in industrial boilers in 2016. Xinjiang and Liaoning burnt a large quantity of petroleum coke in industrial boilers $(0.8$ and 0.5 million tonnes, $14.2 \%$ and $9.7 \%$, respectively). As discussed above, in China, industrial boilers are usually not 
equipped with denitration systems, and therefore, the provinces with high levels of industrial petroleum coke combustion should be subjected to more scrutiny.

Only 10 provinces burnt petroleum coke in power plants. Guangdong burnt 0.6 million tonnes of petroleum coke in 2016, followed by Tianjin (0.6), Zhejiang (0.5), Shandong (0.4), Fujian (0.3), Shanghai (0.3), Beijing (0.2) Henan (0.2), Hunan (0.07), and Jiangxi (0.02) (Figure 6). Although the overall combustion in power plants remained steady over the study period, Fujian, Hunan, and Jiangxi started using petroleum coke to generate electricity and heat in 2012, and Guangdong increased its petroleum coke usage in power plants. These are not positive changes and should be strictly controlled.

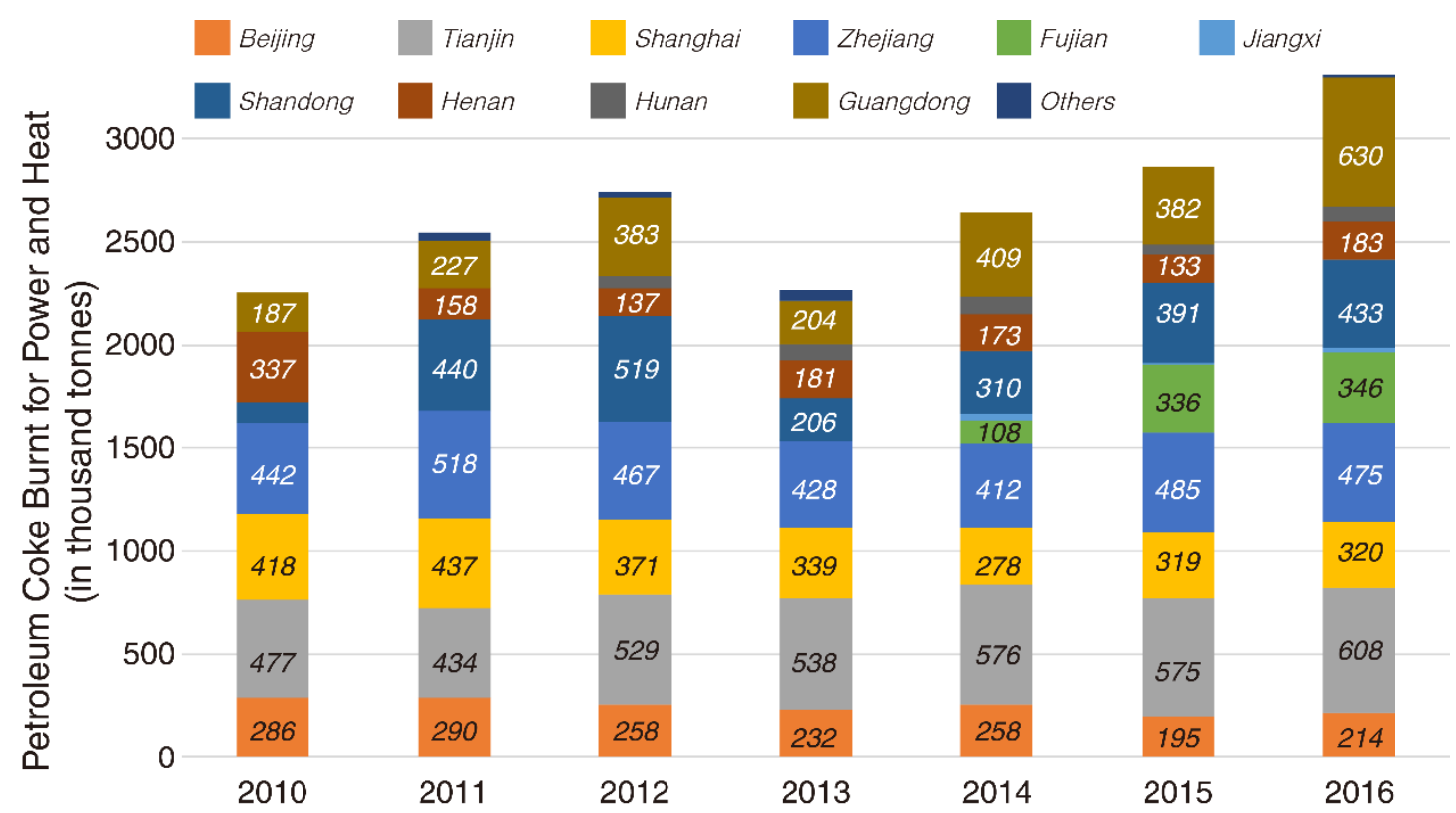

Figure 6. Petroleum coke burnt in power plants for electricity and heat generation by region.

By focusing on the top burning consumption provinces, especially Tianjin and Guangdong, China's government should be able to manage and control the petroleum coke consumption effectively.

\subsection{Petroleum coke-related GHG and air pollutant emissions in China}

Figure 7 and Table 2 present the petroleum coke-related $\mathrm{CO}_{2}, \mathrm{CH}_{4}$, and $\mathrm{N}_{2} \mathrm{O}$ emissions of China and its provinces from 2010 to 2016. 


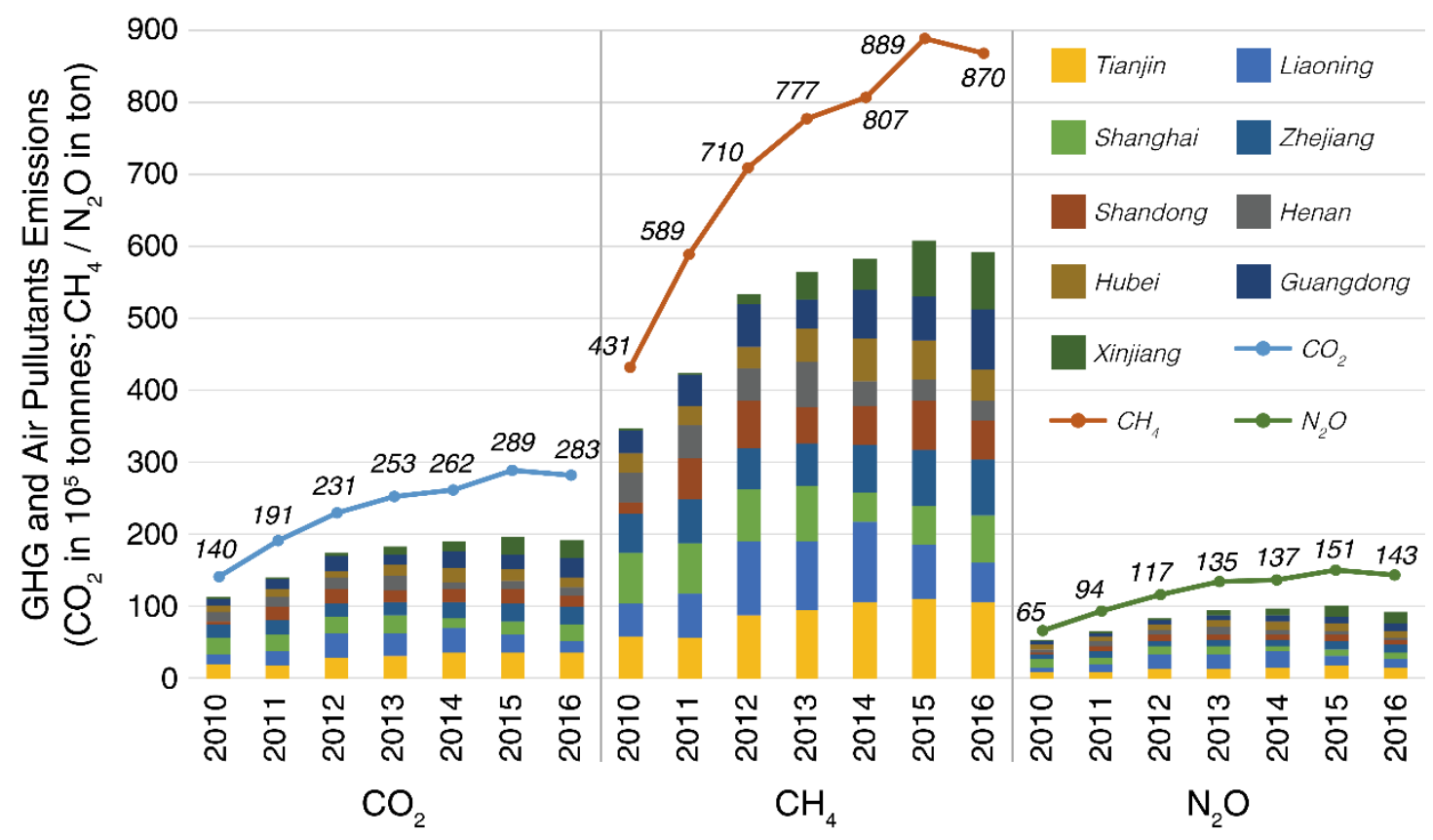

Figure 7. Petroleum coke-related GHG and air pollutant emissions.

Figure 7 shows that the total petroleum coke-related $\mathrm{CO}_{2}$ emissions in 2016 were 28.3 million tonnes, $62.91 \%$ of which (17.8million tonnes) were produced by industrial boilers. The rest of the emissions (37.09\%, 10.5 million tonnes) were contributed by power plants. Because of their relatively low emissions factors, $\mathrm{CO}_{2}$ and $\mathrm{CH}_{4}$ emissions totalled only 869.6 tonnes, and an additional 143.3 tonnes of $\mathrm{N}_{2} \mathrm{O}$ was emitted from petroleum coke burning. Power plants contributed only $23.6 \%$ (33.9 tonnes) of the total $\mathrm{N}_{2} \mathrm{O}$ emissions because of their denitration systems. Thus, most of the $\mathrm{N}_{2} \mathrm{O}$ (109.4 tonnes) was emitted from industrial boilers.

Due to its small consumption, the petroleum coke-related emissions are relatively insignificant compared with China's overall emissions. Take $\mathrm{CO}_{2}$ emissions as example, China emitted 9,217.2 million tonnes of $\mathrm{CO}_{2}$ in 2016, and petroleum coke only accounted for $0.3 \%$. The percentage is also relatively insignificant compared with other major emission sources, such as raw coal $(51.8 \%, 4,771.6$ million tonnes), coke $(25.8 \%, 1,233.4)$, and diesel oil $(10.9 \%, 517.8)$. However, the petroleum coke-related emissions are increasing rapidly. We found that the petroleum coke-related emissions increased rapidly from 2010 to 2015, at an average annual growth ratio of $15.6 \%, 15.6 \%$, and $18.2 \%$ (for $\mathrm{CO}_{2}, \mathrm{CH}_{4}$, and $\mathrm{N}_{2} \mathrm{O}$, respectively). The emissions' overall growing rates during the seven-year study period are $101.6 \%, 101.6 \%$, and $119.0 \%$, respectively, as demonstrated in Figure 7 . This is remarkably high compared to the $16.6 \%$ and $8.3 \%$ growth rate of total and raw coal-related $\mathrm{CO}_{2}$ emissions in China and the overall slight decline that occurred since 2013 [33, 34].

Petroleum coke-related emissions dropped slightly by $2.2 \%, 2.2 \%$, and $5.2 \%$ in 2016 , which was primarily caused by a decrease in petroleum coke combustion in the MNMP sector. The total petroleum coke combustion decreased by 0.196 million tonnes (-2.2\%) in 2016 compared with 2015 level. Except for the MNMP sector, all the other sectors increased their petroleum coke combustion. MNMP decreased petroleum coke combustion by 0.682 million tonnes (-16.4\%). Considering the sector's sales value increased by $5.1 \%$ (306.9 billion Yuan), it already took some actions to stop burning petroleum coke in its industrial builders. 
Meanwhile, the PSEH sector increased its petroleum coke combustion by 0.463 million tonnes (15.5\%) in 2016 to generate more electricity and heat.

Similar to the consumption distribution, the emissions levels were attributable to the few main petroleum coke-consuming provinces, especially Tianjin and Guangdong. Take $\mathrm{CO}_{2}$ emissions as an example: Tianjin and Guangdong contributed $12.26 \%$ and $9.09 \%$, respectively, of the total $\mathrm{CO}_{2}$ emissions in 2016. In contrast, the contribution of Shanghai decreased from $16.6 \%$ to $7.6 \%$ over the seven-year study period, while in Xinjiang, $\mathrm{CO}_{2}$ emissions increased rapidly from 0\% to 9.0\%. Detailed emissions results are shown in Table 2.

Table 2. Petroleum coke-related GHG and air pollutant emissions.

\begin{tabular}{|c|c|c|c|c|c|c|c|c|c|c|c|c|}
\hline & & $\begin{array}{l}\text { Chin } \\
a\end{array}$ & $\begin{array}{l}\text { Tianj } \\
\text { in }\end{array}$ & $\begin{array}{l}\text { Liao } \\
\text { ning }\end{array}$ & $\begin{array}{l}\text { Shan } \\
\text { ghai }\end{array}$ & $\begin{array}{l}\text { Zheji } \\
\text { ang }\end{array}$ & $\begin{array}{l}\text { Shan } \\
\text { dong }\end{array}$ & $\begin{array}{l}\text { Hena } \\
\mathrm{n}\end{array}$ & $\begin{array}{l}\text { Hub } \\
\text { ei }\end{array}$ & $\begin{array}{l}\text { Gua } \\
\text { ngdo } \\
\text { ng }\end{array}$ & $\begin{array}{l}\text { Xinji } \\
\text { ang }\end{array}$ & $\begin{array}{l}\text { Othe } \\
\text { rs }\end{array}$ \\
\hline \multirow{7}{*}{$\begin{array}{l}\mathrm{CO}_{2} \\
\left(10^{5}\right. \\
\text { tonne } \\
\text { s) }\end{array}$} & 2010 & 140 & 19 & 14 & 23 & 17 & 6 & 13 & 9 & 10 & 0 & 9 \\
\hline & 2011 & 191 & 18 & 20 & 23 & 20 & 18 & 15 & 9 & 14 & 1 & 9 \\
\hline & 2012 & 231 & 28 & 33 & 23 & 18 & 22 & 15 & 10 & 20 & 4 & 8 \\
\hline & 2013 & 253 & 30 & 32 & 25 & 19 & 17 & 20 & 15 & 14 & 12 & 7 \\
\hline & 2014 & 262 & 35 & 36 & 13 & 21 & 18 & 11 & 19 & 23 & 14 & 8 \\
\hline & 2015 & 289 & 36 & 24 & 18 & 25 & 22 & 10 & 18 & 20 & 25 & 36 \\
\hline & 2016 & 283 & 35 & 17 & 21 & 25 & 17 & 9 & 14 & 28 & 25 & 35 \\
\hline \multirow{7}{*}{$\begin{array}{l}\mathrm{CH}_{4} \\
\text { (ton) }\end{array}$} & 2010 & 431 & 58 & 45 & 72 & 54 & 17 & 40 & 27 & 32 & 0 & 28 \\
\hline & 2011 & 589 & 57 & 61 & 71 & 61 & 55 & 46 & 29 & 43 & 2 & 28 \\
\hline & 2012 & 710 & 87 & 103 & 72 & 57 & 66 & 45 & 30 & 60 & 13 & 25 \\
\hline & 2013 & 777 & 94 & 97 & 77 & 60 & 51 & 62 & 46 & 42 & 37 & 23 \\
\hline & 2014 & 807 & 107 & 110 & 41 & 66 & 56 & 34 & 58 & 70 & 43 & 25 \\
\hline & 2015 & 889 & 111 & 73 & 56 & 76 & 68 & 30 & 54 & 62 & 77 & 111 \\
\hline & 2016 & 870 & 107 & 53 & 66 & 78 & 54 & 28 & 42 & 86 & 78 & 107 \\
\hline \multirow{7}{*}{$\begin{array}{l}\mathrm{N}_{2} \mathrm{O} \\
\text { (ton) }\end{array}$} & 2010 & 65 & 7 & 9 & 10 & 7 & 3 & 5 & 5 & 5 & 0 & 4 \\
\hline & 2011 & 94 & 7 & 12 & 10 & 7 & 7 & 8 & 6 & 7 & 0 & 4 \\
\hline & 2012 & 117 & 13 & 21 & 11 & 7 & 8 & 8 & 6 & 8 & 3 & 6 \\
\hline & 2013 & 135 & 14 & 19 & 12 & 8 & 8 & 11 & 9 & 7 & 7 & 6 \\
\hline & 2014 & 137 & 16 & 22 & 6 & 9 & 8 & 5 & 12 & 10 & 9 & 7 \\
\hline & 2015 & 151 & 17 & 15 & 8 & 11 & 10 & 5 & 11 & 9 & 15 & 17 \\
\hline & 2016 & 143 & 16 & 11 & 8 & 11 & 7 & 4 & 8 & 11 & 16 & 16 \\
\hline
\end{tabular}

\section{$4 \quad$ Limitations and future work}

This study has limitations with regard to the following three aspects. Possible future work could be designed based on these limitations.

Firstly, this study only investigates the $\mathrm{CO}_{2}, \mathrm{CH}_{4}$, and $\mathrm{N}_{2} \mathrm{O}$ emissions from the petroleum coke use in China. In fact, more greenhouse gases and air pollutants are emitted during petroleum coke burning, including $\mathrm{SO}_{2}, \mathrm{NO}$, and $\mathrm{NO}_{2}$. This is mainly restricted by the emission factors' availability. The existing databases (such as IPCC [3] and EPA [35]) only provide the $\mathrm{CO}_{2}, \mathrm{CH}_{4}$, and $\mathrm{N}_{2} \mathrm{O}$ emission factors for petroleum coke. Possible future work may measure the emission factors of other greenhouse gases and air pollutants, to provide more accurate emission accounts of petroleum coke combustion. 
Secondly, unlike coal used as a raw material input, which does not emit any $\mathrm{CO}_{2}$ [20], the consumption of petroleum coke for non-energy uses likely results in little emission of GHGs and air pollutants. For example, when petroleum coke is used as a prebaked anode in electrolytic aluminium production (i.e., the SPNM sector), $10 \%-20 \%$ of its sulphur is converted into $\mathrm{SO}_{2}$ and is emitted into the air [36]. Because of the lack of accurate escape ratios and emissions factors, we could not estimate the exact emissions from non-energy uses of petroleum coke. Thus, the actual petroleum coke-related emissions are higher than the values estimated above. As GHG and air pollutant emissions are highly related to physical consumption, they could be controlled effectively by managing the consumption and production of petroleum coke.

What is more, as petroleum coke contains high concentrations of heavy metals, such as silicon, nickel, vanadium, aluminium, and iron [14], polluted industrial waste water and solid wastes will be discharged to the natural environment during the petroleum coke's production and use. Some previous studies have already employed environmental monitoring techniques to evaluate the consequences induced by the toxic heavy metalwastes emitted by petroleum coke use. However, due to the lack of parameters (mainly referring to emission factors), our current study is not able to estimate the heavy metal emissions via petroleum coke's consumption data. Future work will measure the related emission factors and evaluate the overall environmental impacts of petroleum coke use.

\section{Conclusion and implications}

Evidence indicates that petroleum coke is gradually replacing other power fuels in China's industrial enterprises because of its current price advantage. This paper presents China's production and consumption of petroleum coke by sector and region from 2010 to 2016 for the first time. The results show that production increased by $10.9 \%$ (5.7 million tonnes), primarily because of activities in Shandong province (4.5 million tonnes). Shandong, Guangdong, Jiangsu, and Liaoning were consistently the major producers of petroleum coke in China. The total consumption of petroleum coke has increased by $18.9 \%$ since 2010 , and over $60 \%$ of the total consumption is as a raw material in industrial processes. The other $40 \%$ is burnt in power plants and industrial kiln stoves/boilers. This usage is the major source of emissions and should be considered as a key regulatory target. The combustion consumption of petroleum coke is focused in the MNMP and PSEH sectors and in Liaoning and Tianjin provinces. The consumption in industrial kiln stoves/boilers increased by approximately $101.6 \%$ during the past seven years, reaching 8.9 million tonnes in 2016 .

Because of the increased petroleum coke consumption in China, GHG and air pollutant emissions are increasing annually. Petroleum coke-related $\mathrm{CO}_{2}$ emissions in 2014 were as high as 28.3 million tonnes, whereas those of $\mathrm{CH}_{4}$ and $\mathrm{N}_{2} \mathrm{O}$ were 869.6 and 143.3 tonnes, respectively. Apart from the largest emissions contributors, Xinjiang, Shandong, and Guangdong exhibited rapid growth in its emissions levels over the seven-year study period. As a result, if no measures are taken, China will face increasingly serious challenges in dealing with climate change and environmental issues.

To manage and control petroleum coke consumption and its related emissions in China, more attention should be focused on the key industrial sectors and top-consuming provinces. Firstly, the Chinese government should strengthen the supervision and management of petroleum coke burnt by the MNMP sector and the power plants. Especially, the power plants are quickly increasing its petroleum coke combustion to provide 
power in 2016. Burning petroleum coke to provide power should be discouraged. In 2013, the U.S. Environmental Protection Agency stopped issuing new licenses for petroleum coke burning in that country; this strategy may work for China as well. Secondly, the local governments of Xinjiang, Guangdong, Tianjin, Zhejiang could take some more radical actions to control their quick increasing petroleum coke combustion in both industrial boilers and power plants. Thirdly, both academia and petroleum coke consuming enterprises should explore clean utilization approaches of energy sources. For example, all power plants and industrial kiln stoves/boilers should be equipped with more efficient decontamination systems, especially for desulfurization and denitrification. As discussed above, the installation rate of low-NOx boilers in power plants is currently only $70 \%$, and the equipment can only decontaminate $30 \%$ of the total NOx emissions; in addition, no decontamination equipment is installed on industrial boilers for economic reasons. Fourthly, the Chinese government should manage the production of petroleum coke, especially the production and import of high-sulphur petroleum coke should be strongly restricted. High-sulphur petroleum coke not only emits more greenhouse gas/air pollutant emissions, but also produces more sulphur compound wastes compared with desulfurized petroleum cokes. Some desulfurizing technologies should be developed and applied during petroleum coke's production in China [37, 38]. What is more, optimizing and improving the industrial processes which use petroleum coke as process martial is also needed, as the non-energy use of petroleum coke also emits greenhouse gases and air pollutants.

\section{Acknowledgements}

This work was supported by the National Key R\&D Program of China (2016YFA0602604), the Natural Science Foundation of China $(71533005,41629501,71503156,71603086)$, the National Social Science Foundation of China (15CJY058), the UK Economic and Social Research Council (ES/L016028/1), Natural Environment Research Council (NE/N00714X/1), and the Philip Leverhulme Prize.

\section{References}

[1] Guan D, Shan Y, Liu Z, He K. Performance Assessment and Outlook of China's EmissionTrading Scheme. Engineering. 2016;2:398-401.

[2] China's state council. Strategic action plan for energy development (2014-2020). 2014.http://www.gov.cn/zhengce/content/2014-11/19/content 9222.htm

[3] IPCC. IPCC Guidelines for national greenhouse gas inventories 2006. Hayama, Japan: Institute for Global Environmental Strategies (IGES); 2006.

[4] EIA. Emission factors for greenhouse inventories.

2014.https://www.epa.gov/sites/production/files/2015-07/documents/emission-

factors 2014.pdf

[5] Andrews A, Lattanzio RK. Petroleum coke: Industry and environmental issues. Congressional Research Service, Accessed on. 2014.

[6] Wang T. Managing China's petcoke problem. Beijing: Carnegie-Tsinghua Center for Global Policy; 2015.http://carnegietsinghua.org/2015/05/31/zh-pub-60291

[7] Daily El. Petroleum coke has become a serious pollution source. 2015.http://dz.jjckb.cn/www/pages/webpage2009/html/2015-08/03/content 8577.htm

[8] Shan Y, Liu J, Liu Z, Xu X, Shao S, Wang P, et al. New provincial $\mathrm{CO}_{2}$ emission inventories in China based on apparent energy consumption data and updated emission factors. Applied Energy. 2016;184:742-50.

[9] Liu Z. Carbon emissions in china. Berlin, Germany: Springer; 2016. 
[10] Liu Z, Guan D, Wei W, Davis SJ, Ciais P, Bai J, et al. Reduced carbon emission estimates from fossil fuel combustion and cement production in China. Nature. 2015;524:335-8.

[11] Pan K, Zhu H, Chang Z, Wu K, Shan Y, Liu Z. Estimation of coal-related $\mathrm{CO}_{2}$ emissions: the case of China. Energy \& Environment. 2013;24:1309-21.

[12] Shan Y, Čuček L, Varbanov PS, Klemeš JJ, Pan K, Zhu H. Footprints Evaluation of China's Coal Supply Chains. In: Klemeš JJ, Varbanov PS, Liew P, editors. European Symposium on Computer Aided Process Engineering 24th. Budapest, Hungary: Elsevier; 2014. p. 1879-84

[13] He K, Huo $\mathrm{H}$, Zhang $\mathrm{Q}$, He D, An F, Wang $\mathrm{M}$, et al. Oil consumption and $\mathrm{CO}_{2}$ emissions in China's road transport: current status, future trends, and policy implications. Energy policy. 2005;33:1499-507.

[14] Caruso JA, Zhang K, Schroeck NJ, McCoy B, McElmurry SP. Petroleum coke in the urban environment: A review of potential health effects. International journal of environmental research and public health. 2015;12:6218-31.

[15] Mckee RH, White R. The mammalian toxicological hazards of petroleum-derived substances: An overview of the petroleum industry response to the high production volume challenge program. International journal of toxicology. 2014;33:4S-16S.

[16] Wang J, Anthony EJ, Abanades JC. Clean and efficient use of petroleum coke for combustion and power generation. Fuel. 2004;83:1341-8.

[17] Zou JH, Zhou ZJ, Wang FC, Zhang W, Dai ZH, Liu HF, et al. Modeling reaction kinetics of petroleum coke gasification with $\mathrm{CO}_{2}$. Chemical Engineering and Processing: Process Intensification. 2007;46:630-6.

[18] NDRC. 10 key energy conservation projects during $11^{\text {th }}$ five-year plan (2006-2010). 2006.http://www.sdpc.gov.cn/fzgggz/hjbh/injs/200608/t20060802 78947.html

[19] MEP. The state council issues action plan on prevention and control of air pollution introducing ten measures to improve air quality. 2013.http://english.sepa.gov.cn/News service/infocus/201309/t20130924 260707.shtml

[20] Peters GP, Weber C, Liu J. Construction of Chinese energy and emissions inventory. Trondheim, Norway: Norwegian University of Science and Technology; 2006.

[21] Shan Y, Guan D, Liu J, Mi Z, Liu Z, Liu J, et al. Methodology and applications of city level $\mathrm{CO}_{2}$ emission accounts in China. Journal of Cleaner Production. 2017;161:1215-25.

[22] NBS. China energy statistical yearbook 2011-2017. Beijing, China: China Statistics Press; 2011-2017.

[23] Guan D, Liu Z, Geng Y, Lindner S, Hubacek K. The gigatonne gap in China's carbon dioxide inventories. Nature Climate Change. 2012.

[24] Zhao B, Wang SX, Liu H, Xu JY, Fu K, Klimont Z, et al. NO ${ }_{x}$ emissions in China: historical trends and future perspectives. Atmospheric Chemistry and Physics. 2013;13:9869-97.

[25] Gordon D, Brandt A, Bergerson J, Koomey J. Know your oil: creating a global oil-climate index. Washington, US: Carnegie Endowment for International Peace, Publications Department; 2015.

[26] Khoudouri W. China's middle east energy strategy. Al-Monitor the Pulse of the Middle East; $\quad$ 2014.http://www.al-monitor.com/pulse/business/2014/05/china-middle-east-oilinterests.html

[27] Oilfield $\quad$ SS. $\quad$ Petroleum

Refineries.http://slof.sinopec.com/slof/domain/petrol processing/

[28] CNPC DOo. Petroleum Refinery and Petrochemcial Industry.http://dqyt.cnpc.com.cn/dq/syhg/cpjs common.shtml

[29] EIA. Petroleum and other liquids: Exports by destination. 2016.https://www.eia.gov/dnav/pet/pet move expc a EPPC EEX mbbl a.htm

[30] Society of petroleum engineers. Unit conversion

factors.http://www.spe.org/industry/unit-conversion-factors.php 
[31] The economist. China's slowdown: from a very big base. 2015.http://www.economist.com/blogs/freeexchange/2015/01/chinas-slowdown

[32] Stochman L. Petroleum Coke: The Coal Hiding in the Tar Sands. In: International OC, editor.2013.http://priceofoil.org/2013/01/17/petroleum-coke-the-coal-hiding-in-the-tar-

sands/

[33] Guan D, Meng J, Reiner DM, Shan $Y, M i ~ Z$, Zhang N, et al. Drivers of China's $\mathrm{CO}_{2}$ emissions 2007-2016. Nature Geoscience. 2018; In press.

[34] Shan Y, Guan D, Zheng H, Ou J, Li Y, Meng J, et al. China $\mathrm{CO}_{2}$ emission accounts 19972015. Scientific Data. 2018;5:170201.

[35] EPA. Greenhouse Gas Inventory Guidance: Direct Emissions from Stationary Combustion Sources.

2016.https://www.epa.gov/sites/production/files/201603/documents/stationaryemissions 3 2016.pdf

[36] Zhao Y, Tian SC, Guo J, Wang R, Tian F. Effect of sulfur content in high-sulphur petroleum coke on prebaked anode in quality and environment. Yunnan Metallurgy. 2010;39:43-6.

[37] Xiao J, Zhang Y, Zhong Q, Li F, Huang J, Wang B. Reduction and Desulfurization of Petroleum Coke in Ammonia and Their Thermodynamics. Energy \& Fuels. 2016;30:3385-91.

[38] Chen Z, Ma W, Wei K, Wu J, Li S, Zhang C, et al. Detailed vacuum-assisted desulfurization of high-sulfur petroleum coke. Separation and Purification Technology. 2017;175:115-21. 